Trivent Publishing

(C) The Authors, 2016

Available online at http://trivent-publishing.eu/

Series: Philosophy, Communication, Media Sciences

Volume: Communication Today: An Overview from Online Journalism to Applied Philosophy

\title{
Landmarks and Perspectives of Education in the Jiu Valley on the Collective Opinion Level
}

\author{
Ion Hirghiduş, ${ }^{1}$ Ioan-Valentin Fulger ${ }^{2}$ \\ ${ }^{1}$ Department of Socio-Human Sciences, Faculty of Sciences, University of Petrosani, Romania, \\ ionhirghidus@yahoo.com \\ ${ }^{2}$ Department of Socio-Human Sciences, Faculty of Sciences, University of Petrosani, Romania, \\ ValentinFulger@upet.ro
}

\begin{abstract}
Education in Romania is facing a crisis nowadays. From the complexity of evolution from a central economy (and, implicitly, a central education), to a capitalist economy and an educational system that aligns itself to European standards, a series of negative opinions emerge regarding the future of schooling. Therefore, an important part of the citizens of the Jiu Valley (Romania) and, probably, of Romania altogether are still looking for landmarks which date from communist education. At the moment there are no viable governmental programs meant to reduce school dropout, which makes Romania a vulnerable country.
\end{abstract}

\section{Keywords}

Education; crisis; poverty; unemployment; communism; capitalism; social policies.

This is an Open Access article distributed in accordance with the Creative Commons Attribution Non Commercial (CC-BYNC-ND 4.0) license, which permits others to copy or share the article, provided original work is properly cited and that this is not done for commercial purposes. Users may not remix, transform, or build upon the material and may not distribute the modified material (http://creativecommons.org/licenses/by-nc/4.0/) 


\section{Introduction}

Education must represent for Romania (and implicitly for the Jiu Valley) a major priority. Passing from the communist system to a step-by-step building of capitalism has lead to certain changes in education by imposing new standards. A new society needs new education. Unfortunately, reforming Romanian education has and still is slowly taking pace mainly because old patterns are maintained and opinions which place communist education on a favourable position are compared to the structural changes that were made in the last 25 years.

The importance of education is essential since reaching the objectives set through educational planning also means its perfection, the individual who is subjected to education. As Cristina Neamţu said, "Education is currently perceived as a vital function of contemporary society because through education society perpetuates its own existence, passing on from generation to another everything humanity has learnt about itself and about reality." Education achieves the progress of man and society which is determined by the reached educative goals. What happens with these goals or ideals? if they're not turned into reality? It might be an example for the crisis that education faces at the present time, crisis that was acknowledged a long time ago in western society. Even reaching a high technological level in a society might lead to educational conflicts between the basic needs of the human society as generations progress, according to Hannah Arendt: "A crisis in education would at any time give rise to serious concern even if it did not reflect, as in the present instance it does, a more general crisis and instability in modern society. For education belongs among the most elementary and necessary activities of human society, which never remains as it is but continuously renews itself through birth, through the arrival of new human beings." ${ }^{2}$ The crisis of education comes from a general instability of modernity because this instability is accepted as inherent dynamics of social phenomenology. Modernity brings radical changes in what regards man's attitude towards self, by releasing from the idea of a set social stratification. This type of instability is more and more linked to the freedom of man that was constructed at conscience level. The question is what constitutes the crisis in education, if this crisis can be considered a drive for change. Some authors, such as Hannah Arendt claims that modernity, by gradually imposing individual freedom also means a crisis of authority. Therefore, we must ask ourselves which authorities have to suffer: the authority of the monarch, institutional authorities, authority of religion, authority of tradition, authority of education etc.

"The crisis of authority in education is most closely connected with the crisis of tradition that is with the crisis in our attitude toward the realm of the past. This aspect of the modern crisis is especially hard for the educator to bear, because it is his task to mediate between the old and the new, so that his very profession requires of him an extraordinary respect for the past." 3

The meaning that Hannah Arendt gives to the authority crisis in education may partially be applied for countries that went from a communist regime to capitalism, fact that contradicts the foresight of Karl Marx who stated that communism is the ultimate society, a type of society to be found in developed capitalist countries after undergoing transformation to communism. The attitude towards the past, especially in a period of transition, when reforms are not yet functional, may be nostalgia. This often happens in Romania because reforms are not fully functional even after 25 years since the overthrow of the communist regime. The most obvious for observations is the educational system, where reforms brought only facade changes. Despite the fact that Romanian education aligned itself

\footnotetext{
${ }^{1}$ Cristina Neamţu, "Aspecte ale asistenţei sociale în şcoală," [Aspects of social assistance in schools] in Tratat de asistenţă socială [Treatise on social assistance], ed. George Neamțu (Iași: Editura Polirom, 2011), 998.

${ }^{2}$ Hannah Arendt, Between past and future. Six Exercises in Political Thought (New York: The Viking Press, 1961), 185.

${ }^{3}$ Ibidem, 193.
} 
with the western structures, especially at university level, we are still challenged by anchors set in the past. Because it's an approximate recent historical memory, the advantages of socialist arrangements have not been forgotten. Moreover, these advantages are weighed against the situation of current Romanian school that produces specialists condemned to unemployment right after graduation. In socialism, graduates were immediately employed based on their specialty, something that does not happen today. A situation of the statute of Romanian school is presented in a wider context by Laura B. Perry: "The global resurgence of political democratisation that occurred in the early 1990s brought about many education reforms in central and eastern Europe. Schooling in the communist era was highly centralised and prescribed, affecting all levels and aspects of the education system, such as curricula, textbooks and funding. After the end of communism, the main approaches for democratising schooling were to decentralise and diversify the education system and to make schools more open to the participation of parents and communities." The end of communism in Romania has lead to a slow and relatively narrow decentralisation for school education and a quicker one for university education. The phenomenon of decentralisation is determined by the degree of democratisation of education. Therefore in towns there is an increase of involvement from parents and the community when making local decisions.

\section{The phenomenon of redundancy in the Jiu Valley mining and its social effects}

The Jiu Valley has represented a less evolved area of Romania since mining began in the $19^{\text {th }}$ century, however the state of socio-economic backwardness is still encountered in the $20^{\text {th }}$ century. Even more, this regression can be seen today, a quarter of a century away since the revolution that lead to the fall of Ceaușescu's communist regime. In this economic context we can also see the educational issues that are determined by the regression of mining. Therefore, the phenomenon of mining redundancy is a direct cause of the education crisis from this mining area, even if it's kept under relative control by the national decisional factors.

This phenomenon is best regarded under its cobra effects because the outcomes signify major social problems that may imply maladjustment to the situation.

A social issue is defined, in general terms, as a "feature, situation appeared in a social system's dynamics that negatively affects it's functioning and requires interventions to correct (modity), eliminate." ${ }^{5}$ R.K. Merton defines the social problem as a "significant discrepancy between social norms and social reality" (R.K. Merton, R.A. Nisbet, Contemporary Social Problems, 1961). ${ }^{6}$ The social problem is a generic term therefore "the variety of possible social problems is almost infinite, it may encompass phenomena like a drop in literacy standards, to the disappearance of work ethics. In a similar fashion, the proposed solutions are just as varied, partially because of different values and interests of involved parties"7

\footnotetext{
${ }^{4}$ Laura B. Perry, "Democratic Aspects of Communist and Post-communist Schooling in Central and Eastern Europe," in Logics of Socialist Education. Engaging with Crisis, Insecurity and Uncertainty, ed. Tom G. Grif , Zsuzsa Millei, Vol. 24 (New York: Springer Science+Business Media Dordrecht, 2013), 155.

${ }^{5}$ Dicţionar de sociologie [Sociology dictionary], ed. Cătălin Zamfir, Lazăr Vlăsceanu (Bucharest: Editura Babel, 1998), 446.

${ }^{6}$ Ibidem.

${ }^{7}$ Dictionar de sociologie (Oxford) [Sociology dictionary (Oxford)], ed. Gordon Marshall (Bucharest: Univers Enciclopedic, 2003), 444-445.
} 
Studying and explaining social problems and their causes represents the basic concern of most of today's sociologists. Sociologists (and social workers alike) play a central role in identifying certain situations or conditions as social issues and formulating policies to remediate them.

What is in fact a social problem? A probating answer may be given by taking into account an eloquent response offered by C.W. Mills. If in a town with a population of a hundred thousand there is a single unemployed individual, this means that it's a personal matter, and to resolve this, the individual's qualification and character must be considered and the favourable conditions for employment. The situation is totally different when in a country with 50 million employed, 15 million are unemployed because the solution is no longer found within "the sphere of opportunities." This time, the problem affects a human collective, and solving it imposes that after examining personal cases, political and economical institutions of society must also be examined. This problem has a social nature because it cannot be solved at individual level but societal. ${ }^{8}$

One of the most influential sociologists of the $20^{\text {th }}$ century, C. Wright Mills, argued that a complete understanding of social problems and efficient remedies against them places a toll on all individuals, not just on sociologists to develop what he called sociological imagination. Some personal problems, individual may be connected with "public issues."

Some social issues are caused by the disinterest of governmental factors, by the lack of effective means of control; others are the consequences of politico-social revolutions, of sudden changes in social life, in mentality and human behaviour (meaning the deviation from what is considered "normal" in a society). ${ }^{10}$

Among the most investigated present social problems in our country are poverty, felony, unemployment, domestic violence, migration etc. and solving them requires considerable governmental and non-institutional efforts.

According to the Dictionary o Sociology coordinated by Cătălin Zamfir and Lazăr Vlăsceanu, there are more types of causes for social problems: ${ }^{11}$

a. The processes of social disorganisation, crisis, change or development;

b. Personal deviance (social problems generated by the "normal" proportions of deviant individuals within a certain society;

c. Social Problems are processes, situations, social structures for which there are no effective means to control or these means are overcome.

The Jiu Valley is found in the categories of urban areas with regressive industry in which mining has become unprofitable. Restructuring mining activities brought a sudden economic downfall of the area and amplified social issues by rising unemployment. This is the main social issue confronted by the population of the Jiu Valley, from which a multitude of issues derive that make this area one of Romania's most disfavoured.

Redundancy is the phenomenon of reducing the number of employees in a certain economic sector, in this case mining, in order to make economy gainful. The analysis of this phenomenon and its effects on socio-economics is extremely complex. What is certain is that redundancies in Romania were produced, especially in Jiu valley, a new social category that implies new social problems.

Referring to the redundants as a social category, in fact the newest in Jiu Valley, it is easy to ascertain that they do not represent something abstract. We can form a representation accurate enough about this new social class by using seven variables, that manage to draw sufficiently enough the

\footnotetext{
${ }^{8}$ Dumitru Otovescu, Sociologie generală [General sociology] (Craiova: Editura Beladi, 2008), 41.

${ }^{9}$ C. Wright Mills, Imaginaţia sociologică [Sociologic imagination] (Bucharest: Editura Politică, 1975), 78.

${ }^{10}$ Dumitru Otovescu, Sociologie general, 43

${ }^{11}$ Dicţionar de sociologie, ed. Cătălin Zamfir, Lazăr Vlăsceanu, 446.
} 
collective portrait of these people. The seven variables are: gender, region of origin, education, marital status, craft, qualification and age. ${ }^{12}$

The redundancies in mining have lead to an increase in social mobility. The social mobility of each individual is judged by two extreme marks: social origin and the status reached at the end of career. Far from being at the end of their careers, many of the people who make up the new social category of the Jiu Valley currently have an uncertain status, trying, if not forcefully, a sentiment of losing the identity, alienating.

Restructuring and reorganising the area economy, that of the Jiu Valley, is a part of the wider picture for Romania's economical reform. The current reform is identified with the transition to a market economy, its purpose is stopping the crisis and ensuring the normality of economical (and social) life, by aligning to the standards of European economy, towards the structures and mechanism for social welfare.

The process of restructuration gave birth to a long series of needs and social problems. Social needs are expressed as the fraction that exists at a given moment between the state of an individual, group or collective and the state considered to be normal by society. Therefore there are needs acknowledged by the society, and is willing to intervene for their satisfaction. ${ }^{13}$ The intervention of society, or more accurately, the intervention of state, bears the name of social policy and consists of modifying the features of a collective in a desirable way. ${ }^{14}$

The entire Jiu Valley is practically encompassed by destitution, defined and understood as "the lack(insufficient) of material means for life," 15 "a state of permanent lack of resources needed to ensure a what's considered to be a decent way of life, acceptable within a certain collective", "a state of lack of resources (usually material, sometimes cultural)."16

The state of poverty doesn't install itself immediately, since every person may, during their lifetime, have relative short periods of time (a few months) when the income is not enough to ensure a minimum standard of living. Poverty truly inserts itself when the lack of resources is chronic, the people involved consumes previous accumulations. ${ }^{17}$ The definition is perfectly confirmed by the reality of the Jiu Valley where poverty did not install itself suddenly but after approximately a year, year and a half after the redundancies, period of time after people have spent their compensations, went out of unemployment aid and did not manage to find a new job. We bring as argument the numerous social aid and emergency aid that follow the unemployment, however they cease after 270 days since allocation.

The protest of the redundants are well known, they took place in front of Town Halls all over Jiu Valley. The main demand was that of a stable job for an undetermined period of time. There have been extreme cases, widely covered by the local media like those of collective self immolation. Over the passing of time, these movements lost their initial reasons, an aspect caught by the media, which instead of using the term of "meeting of the redundants" used "miling" (derived from "milă,"

\footnotetext{
${ }^{12}$ Ioan Valentin Fulger, Valea Jiului după 1989, spaţiu generator de convulsii sociale [The Jiu Valley after 1989, a space which generated social convulsions] (Petroşani: Editura Focus, 2007), 25-26.

${ }^{13}$ Gabriel Mățăuan, Evaluarea programelor sociale [The evaluation of social programmes] (Buharest: Editura Expert, 1998), 18.

${ }^{14}$ Politici sociale. România în context European [Social policies. Romanian in European context], ed. Elena Zamfir, Cătălin Zamfir (Bucharest: Editura Alternative, 1995), 22.

${ }^{15}$ Dicţionar de sociologie, Cătălin Zamfir, Lazăr Vlăsceanu, 517.

${ }^{16}$ Dicţionar de sociologie (Oxford), ed. Gordon Marshall, 500.

${ }^{17}$ Politici sociale. România în context european, ed. Elena Zamfir, Cătălin Zamfir, 58.
} 
Romanian for pity). The protests gained a pejorative meaning within public opinion, mainly because of 3 factors: ${ }^{18}$

- Many of the redundants declined the township's offer for seasonal jobs (low income jobs)

- The protester accepted within their ranks a number of people that had nothing to do with mining, the syndicate or the redundancies of '97 and '99. Strength in numbers was considered to be a good principle, however a boomerang effect was caused, the movement was discredited even among the opinion of Jiu Valley;

- The birth of objectors, people impossible to satisfy.

Poverty and unemployment - interchangeable phenomena in the Jiu Valley. Poverty and unemployment are interchangeable terms because when we speak of unemployment we can speak of poverty. This is clear in the Jiu Valley, where the unemployment of larger and larger groups that worked in the mining industry has lead to an increase in destitution. Unemployment is a "negative state of economy defined through an unbalance of the labour market through which the workforce offer far surpasses the workforce demand from employers." ${ }^{19}$ From all kinds of unemployment, in Jiu Valley, structural and permanent unemployment is dominant. The unemployed are registered to the International Labour Office: "people aged 14 and above that in the given time frame meet the following conditions: no professional occupation, available to start within the next 15 days, are seeking employment, people that usually are part of the inactive population (students, retired), who seek employment; unemployed that await re-employment. ${ }^{20}$

The restructuring and narrowing of mining in the Jiu Valley had as immediate consequence the placement of this area on the first place within regional statistics regarding unemployment, unemployment rate being the fraction between registered unemployed and the active population (formed by the unemployed and employed, defined as in the workforce balance methodology).

The number of registered unemployed and calculating the said variable for determining the unemployment rate makes the obtained values authentic only for the time reference. The real number of unemployed is significantly larger. In other words, the calculated value of unemployment can only be real only if every person no longer registered were to be employed, something impossible for the referred time frame.

An analysis of Jiu Valley unemployment must consider not only the official data because they do not always reflect reality. Officially, they only consider registered unemployed, however there are many others with no social status. It is claimed that unemployment has dropped in the meantime and in December 2012 it's placed somewhere along 6.7\% of the total active population, something false for the Jiu Valley, where most of the workforce is jobless (at least with no legal forms).

An analysis of social issues in the Jiu Valley, under urban considerations reveals that this part of Romania is confronted by an increased rate of relative and absolute poverty, with an increase of antisocial acts and school dropout.

\section{Methodological aspects of the research}

This paper is written based on a sociological research carried out in the summer of 2014 with the purpose to determine the opinion of the Jiu Valley inhabitants regarding a series of major issues of this area. Among these issues: education and culture, health, social status, unemployment, emigration,

\footnotetext{
${ }^{18}$ Ioan Valentin Fulger, Valea Jiului după 1989, spaţiu generator de convulsii sociale, 32.

${ }^{19}$ Eugen Maniac, Şomajul,. Compendiu legislativ în sprijinul agenţilor economici şi şomerilor [Unemployment. Collection of laws for employers and unemployed] (Deva: Editura Călăuza, 1998), 34.

${ }^{20}$ Ibidem, 11.
} 
aging, aspects of civilisation in globalisation context etc. We chose the Jiu Valley for the purpose of the research because this zone is a particularity in Romania, meaning that the negative aspects of our country can be found here, multiplied. This situation is encountered in all mono-industrial areas that have yet to find viable economical solutions except for the previous economic setting.

Based on these negative aspects, education was also impaired, especially in the balance that must be found between the finished product of school (graduates of a certain speciality) and current labour market demands. The lack of opportunities on the market for university graduates is also the main cause for their emigration.

The targeted population was represented by people aged 18 and over from the Jiu Valley, a sample of 600 subjects was extracted. As a method, the direct sociological inquiry was used and as instrument, the sociological questionnaire made up of 65 questions. For the economy of the questionnaire, 20 questions were strictly meant for educational issues and the capacity of the labour market to assimilate university graduates. We used several identification questions in order to have a wider palette of answers based on gender, age, studies, occupation, marital status, nationality, religion, income etc. Collecting the field data, checking of the questionnaires and statistic calculations was done with the help of sociology students from the University of Petroşani.

\section{The results}

The negative opinions of the people inquired regarding the current education is based on the lack of success of the reforms. Firstly, the reforms did not have a large enough material basis to ensure a significant leap of education. Secondly, the reforms were based on political conjunctures and were socially discontinued because each new government came with new ideas, sometimes opposite to previous rule. This incoherence most likely influenced negatively the opinion of the population about the country's evolution. Based on the research, $51 \%$ of respondents consider that the educational system is below the once from the communist era, both schools and universities. A smaller percentage, $21.16 \%$ evaluates that the educational system has progressed. The other $27.84 \%$ could not decide for this comparison. This discrepancy of opinions is easily visible capitalist society has failed to bring the awaited benefits. The Romanian school is uselessly producing specialists that are currently not needed, which further underlines the economic crisis.

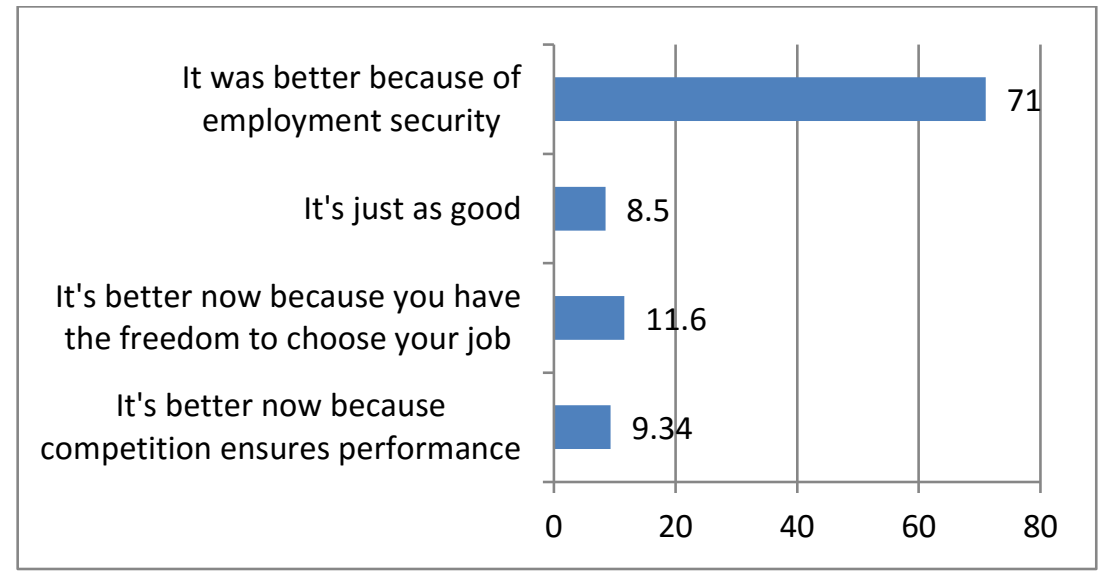

Fig. 1. Opinion regarding job allocations for students under communism and the lack of allocation in nowadays society $(\%)$ 
An element of discontent about the post-Decembrist age is the lack of finality for studies. During communism, all high school and all university graduates were allocated to the work market. In almost every situation, the average educated and highly educated person were working within their qualification which was a professional advantage. This system was abandoned since 1990. It could no longer function because the economic activities were narrowed drastically: a lot of companies disappeared, reductions in agriculture, decrease in commerce, tourism regressed, less governmental jobs, while private sector was always insufficient compared to the available workforce.

On this foundation of socio-economic phenomenology the answers of the questioned people must be regarded. $71 \%$ of them consider that the allocation of graduates in communism was better compared to the freedom of choice in workplace and stimulating performance. The mandatory allocations ensured employment and social security. This is more obvious in the Jiu valley, as the region is confronted by the same problems as mono-industrial areas. Mining absorbed most of the local workforce and also other people relocated here from other parts of the country. They were attracted by the high income, severance payments, and early retirements (around 45 years of age).

Romania, as the other countries of the former socialist block had to take important steps in its evolution that lead to joining NATO (29th of march 2004) and the European Union (1st of January 2007). Gradually, the overall situation improved considerably since the crisis periods following the 1990s. Not only economy was targeted, but rather enforcing democracy that was always endangered by a long stream of corruption. The general economic crisis of 2010 in Europe has affected severely Romania, where living standards were significantly lowered by reductions in incomes by $25 \%$ and other monetary rights were not accorded. This crisis was accompanied by moral recoil with negative effects for education. Many parents could not afford to send their children to school anymore. An increased number of parents were required to emigrate for work, leading to an increase of school dropouts. It is estimated that in 2010, over 100000 children dropped out of school.

Based on this situation, the opinions o the citizens of the Jiu Valley are negative when it comes to evolution of education on two comparative scenarios: 2009-2011 and 2012-2014.

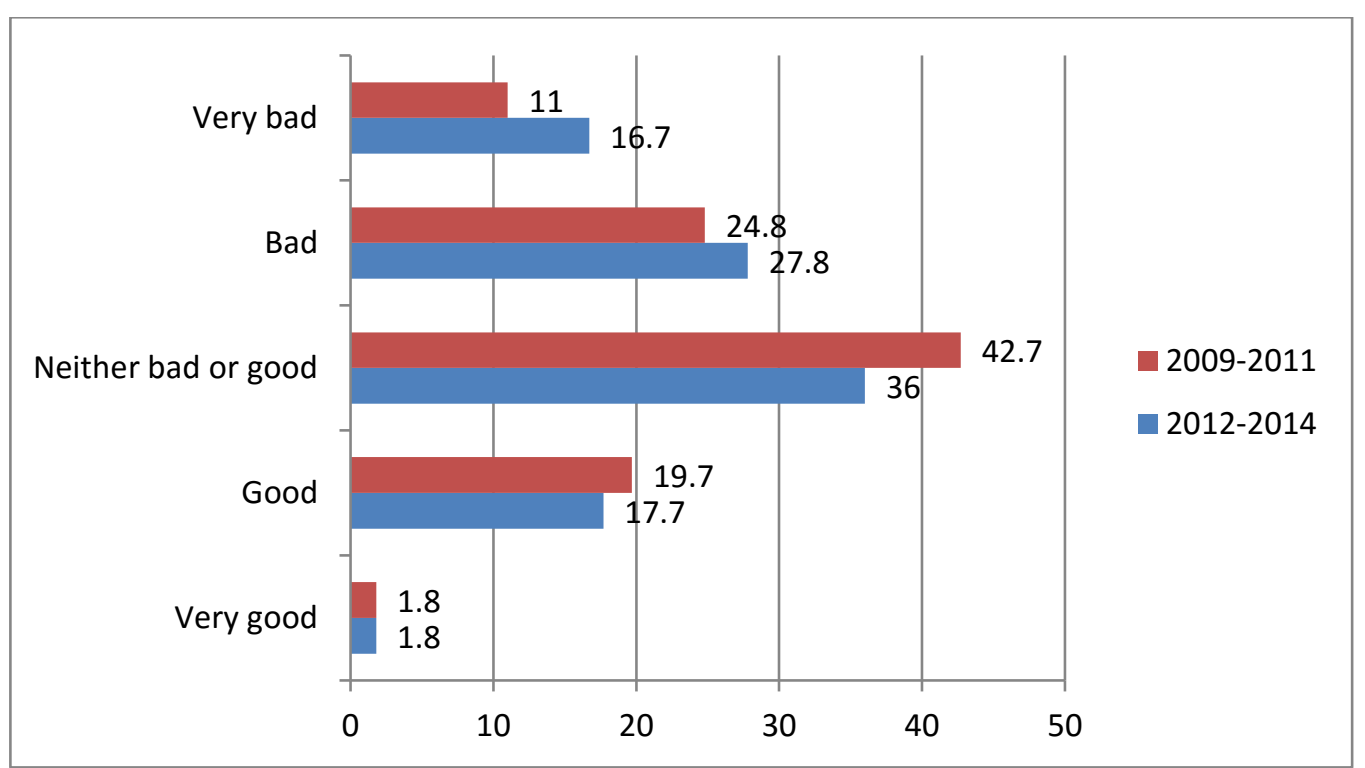

Fig. 2. Comparison regarding the evolution of education between two distinctive time frames (\%)

The general economic crisis, restrictions of mining, poor development of productive sectors have led to an increase in negative opinions. It is observable that from the statistical data of questioned 
citizens there is a degradation in public education in 2012 to 2014 compared to 2009-2011. These opinions are mostly normal considering the facts. Before the official instalment of the crisis (2010) the number of students and pupils is larger, the income of faculties are acceptable, income in mining is consistent. Gradually, after the instalment of the crisis, there is an increase in unemployment both in public sector and in private. The number of people earning below minimum wage increases. In 2012, Romania is officially out of the crisis, but in reality, the situation continues with destituted families.

The destitution of families involves school dropout. It's quite clear that a bat material status leads to dropout for most kids from low income families that are unable to support their education. Also, it's important to consider that destituted families are in a state of moral degradation and effectively lose interest for education. Education might be considered a fad especially that after graduating there is no employment. In best case scenario, 8 classes is the limit for poor families. There are few destituted children that graduate high school and even less that become university graduates. Even after such efforts which usually represent employing the young in unqualified labour, there is no guarantee of a good income job.

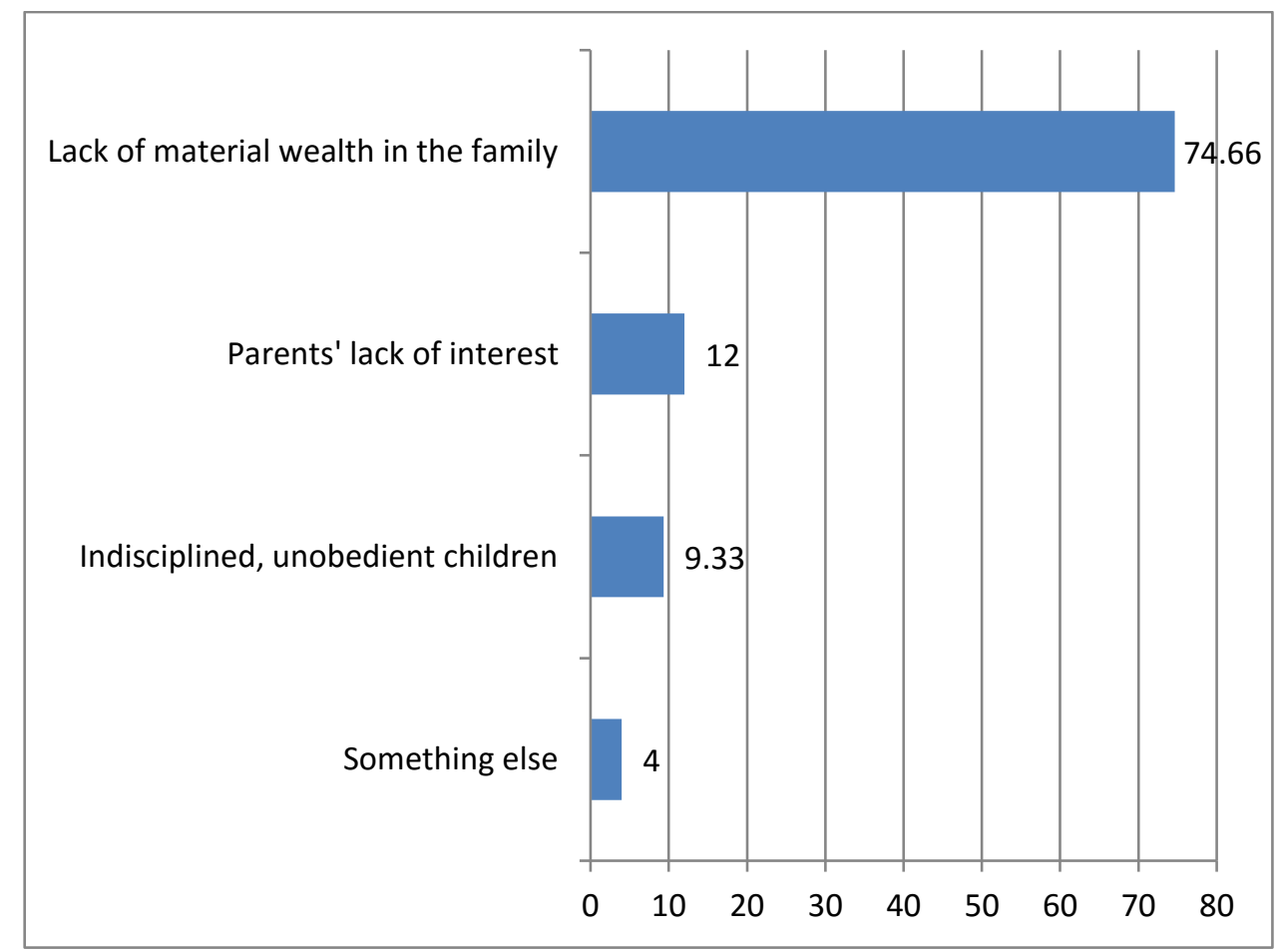

Fig. 3. Causes that determine school drop-out in general (\%)

We see that for most questioned subjects, $74,66 \%$, the main cause that leads to dropout is destitution. It's the normal way of things because many of these families do not have enough to procure food, to maintain a household. Therefore, the risk of lacking education by dropout is high.

Another cause, but only for $12 \%$, that leads to dropouts is the lack of interest manifested by parents. There are some parents that are not interested in education because it is possible that they are in fact not educated. A third cause, less important than the first two is the indiscipline of children that are out of parental and school control. 


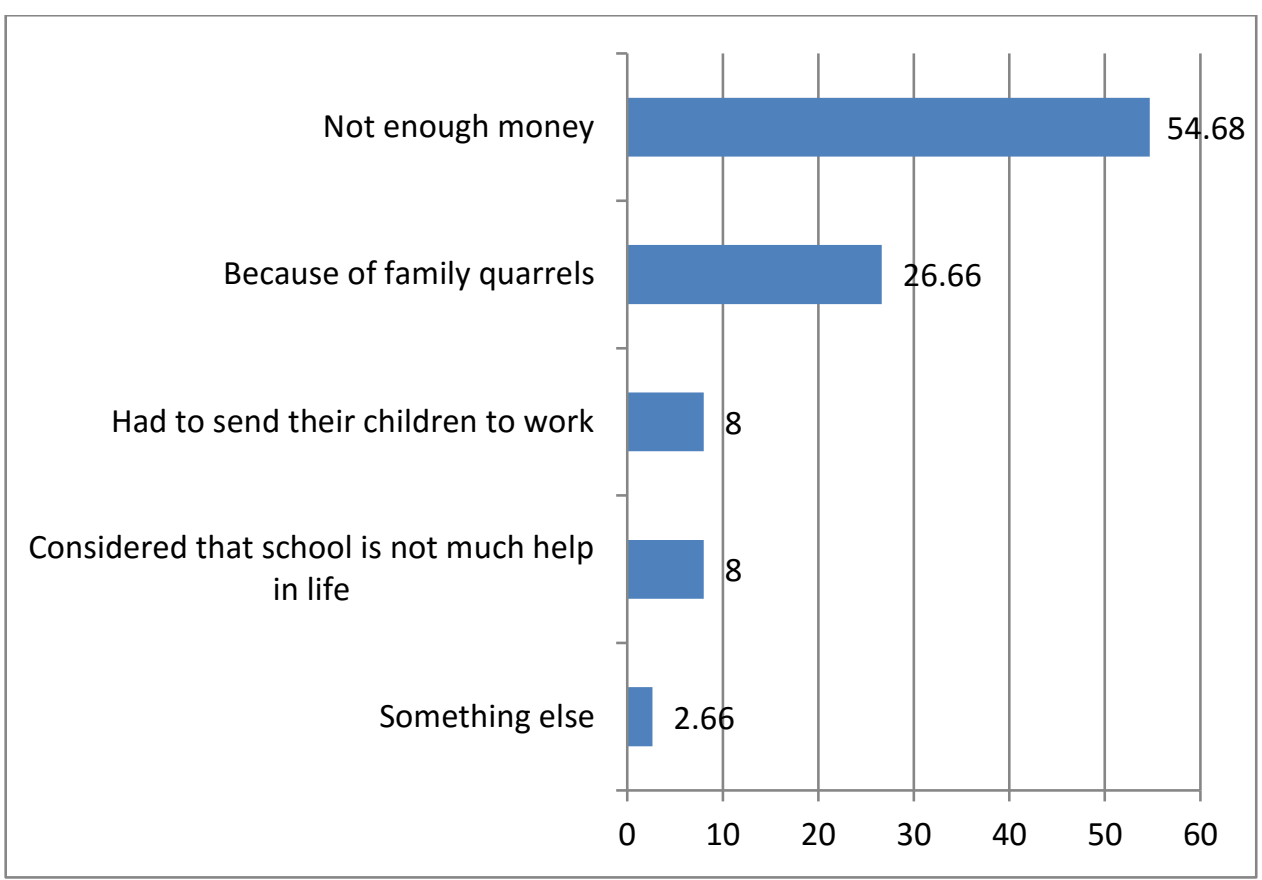

Fig. 4. The causes that determined school dropout of own children (\%)

We observe that even in case of their own children dropping out, destitution is primal with $54.68 \%$. It is however a lower percentage than that in the previous graph $(74.66 \%)$

An important cause for the questioned subjects that leads to their own children dropping out is family quarrels ranging $26.66 \%$. Probably these quarrels are caused by poverty, alcohol abuse and adultery.

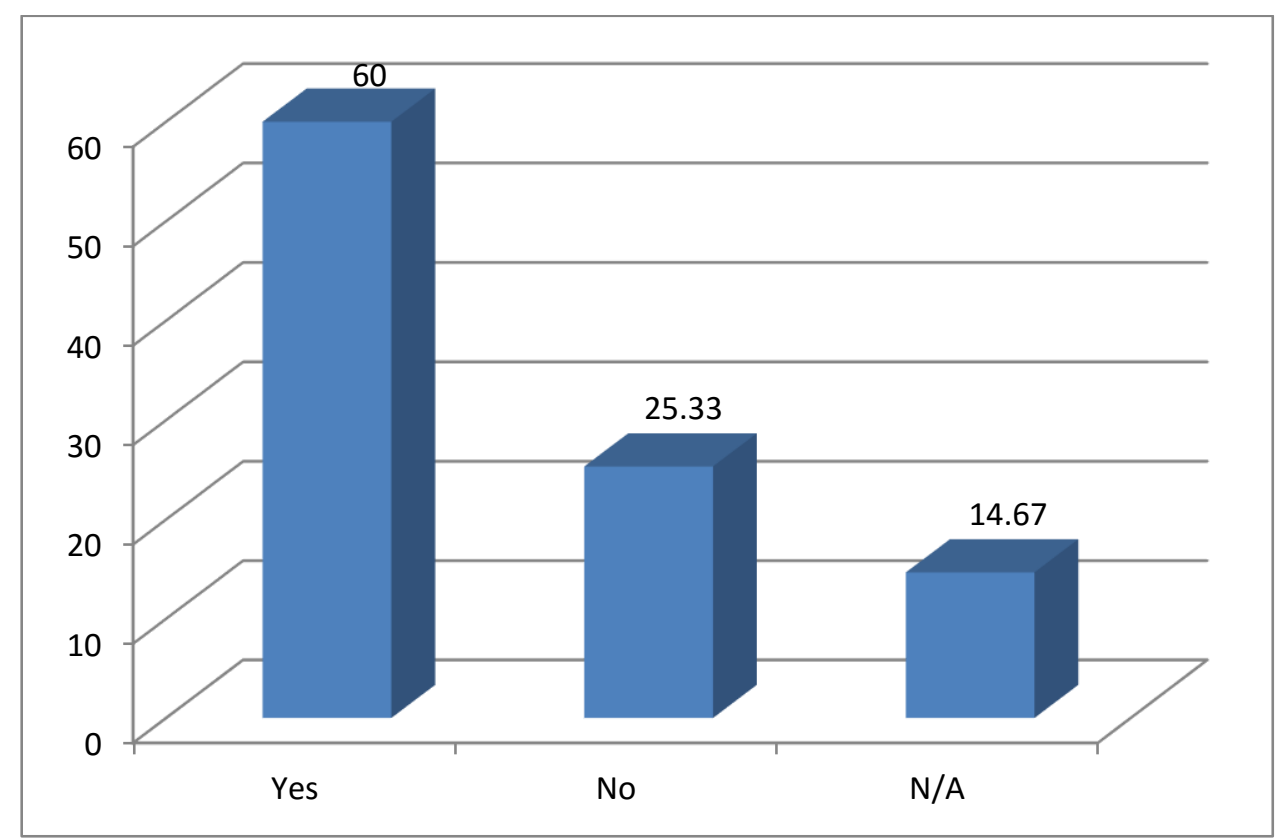

Fig. 5. More money would determine the reduction of school dropout (\%)

We notice that most of the subjects questioned (60\%) consider that if they had more money they would send their children to school. 
An important percentage of 25.33 consider that even if they had more money, their children would not attend school. If we further investigate why they chose such an answer we would reach more sensible causes than the lack of money.

A percentage of 14.67 cannot answer if having more money may determine a reduction of dropout by resuming school. Probably this category considers other causes and money cannot eliminate this negative phenomenon with devastating effects nationwide.

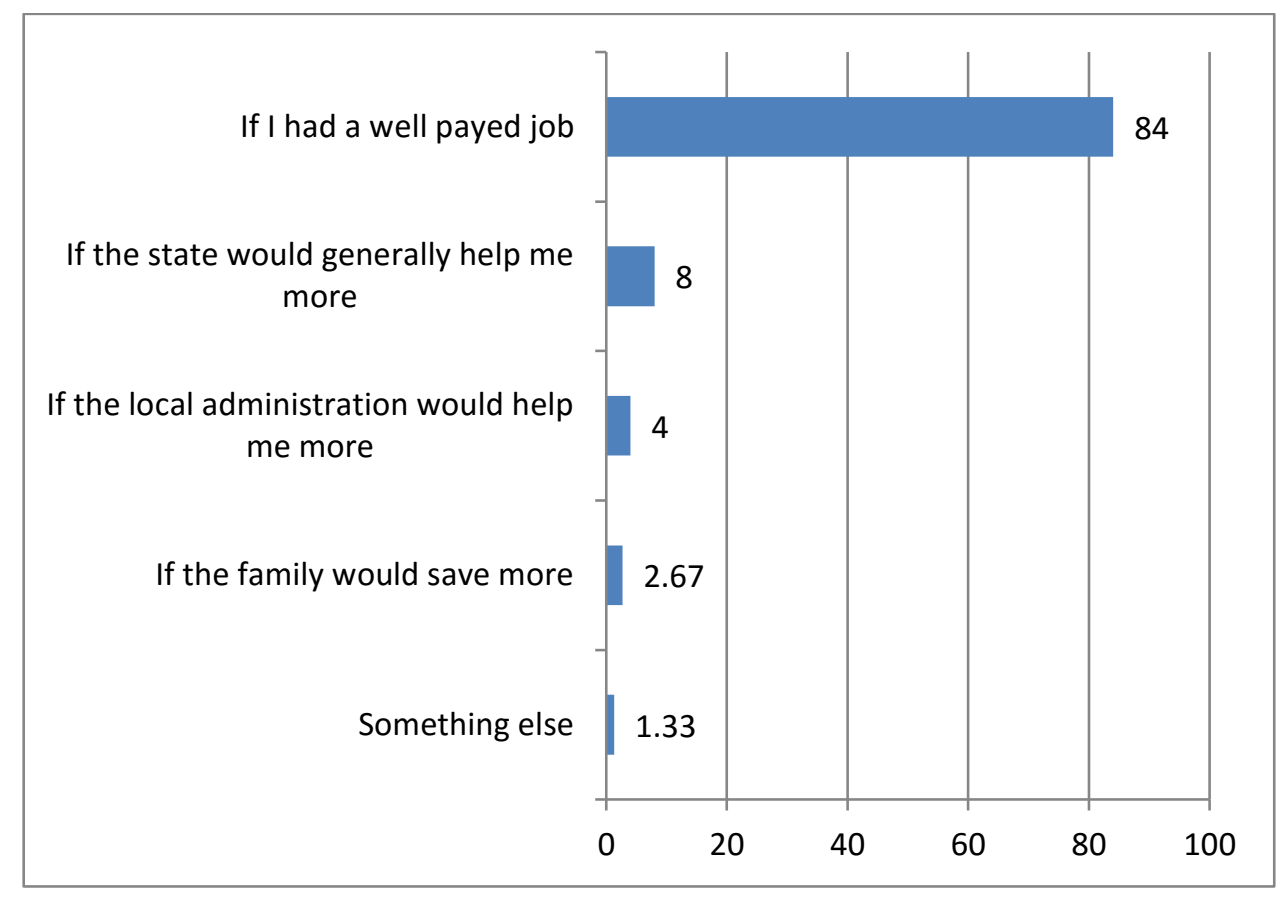

Fig. 6. Possible sources to grant higher income (\%)

Most of the questioned subjects, making up to $84 \%$, consider that if they had a high income job would solve the family's problems including dropout.

The acute lack of jobs, especially in disadvantaged areas of our country, represents an extremely severe reality. This determines a series of negative phenomena like school dropout. It is to be considered that a small percentage of the subjects claim that the state must financially support them through central and local administrations. Probably the expectations of the said subjects are minimal regarding the state and local administrations by knowing the widespread of corruption and the lack of political will of the elected.

\section{Conclusion}

This paper reveals the fact that poverty is a severe plague, with outstanding consequences on families. Because of destitution there is a lack of future perspective or if this perspective exists, it is grim. We've seen that an important number of subjects claim that they will not send their children to school any longer. The following reasons are called in the content of the paper: lack of money, not trusting school, not believing in education in general. Impoverished families are not sufficiently supported by the state or the local administration. The state of destitution is firstly attributed to the lack of jobs. Only $21,33 \%$ of the subjects are employed, while the rest of $70.67 \%$ are unemployed or do not have an occupational status. In order for the situation to not further degenerate, efficient social programs are needed that must be carried out both by state institutions and NGOs. 


\section{References}

Arendt, Hannah. Between past and future. Six Exercises in Political Thought. New York: The Viking Press, 1961.

Fulger, I-V. Valea Jiului după 1989, spaţiu generator de convulsii sociale [The Jiu Valley after 1989, a space which generates social convulsions]. Petroşani: Editura Focus, 2007.

Maniac, Eugen. Şomajul. Compendiu legislativ în sprijinul agenţilor economici şi şomerilor [Unemployment. Collection of laws for employers and unemployed]. Deva: Editura Călăuza, 1998.

Marshall, Gordon (ed.). Dicţionar de sociologie (Oxford) [Sociology dictionary (Oxford)]. Bucharest: Univers Enciclopedic, 2003.

Măţăuan, Gabriel. Evaluarea programelor sociale [The evaluation of social programmes]. Bucharest: Editura Expert,1998.

Mills, C. Wright. Imaginaţia sociologică [Social imagination]. Bucharest: Ed. Politică, 1975.

Neamţu, Cristina. "Aspecte ale asistenţei sociale în şcoală” [Aspects of social assistance in schools]. In Tratat de asistenţă social [Treatise of social assistance], ed. George Neamţu, 997-1094. Iaşi: Editura Polirom, 2003.

Otovescu, Dumitru. Sociologie generală [General sociology]. Craiova: Editura Beladi, 2008.

Perry, Laura B. "Democratic Aspects of Communist and Post-communist Schooling in Central and Eastern Europe". In Logics of Socialist Education. Engaging with Crisis, Insecurity and Uncertainty, ed. Grif, Tom G. and Millei, Zsuzsa, Vol. 24. New York: Springer Science+Business Media Dordrecht, 2013.

Zamfir, C. and L. Vlăsceanu. (ed.). Dicţionar de sociologie [Sociology dictionary]. Bucharest: Editura Babel, 1998.

Zamfir, E. and C. Zamfir, C. (ed.). Politici sociale. România în context European [Social policies. Romania in European context]. Bucharest: Editura Alternative, 1995. 